\title{
FIRST RESULTS OF THE SEARCHING OF ASTEROIDS BASED ON THE DATA OF FON-DUSHANBE PROCESSED PLATES
}

\author{
O. M. Yizhakevych ${ }^{1}$, A. Sh. Mullo-Abdolov ${ }^{2}$, H. V.Relke $^{3}$, \\ G. I. Kokhirova ${ }^{2}$, L. K. Pakuliak ${ }^{1}$, V. M. Andruk ${ }^{1}$ \\ ${ }^{1}$ Main Astronomical Observatory of NASU, Kyiv, Ukraine, izhak@mao.kiev.ua \\ ${ }^{2}$ Institute of Astrophysics of AS of Republic of Tajikistan, Dushanbe, \\ Tajikistan, aziz.sherzod@gmail.com \\ ${ }^{3}$ Walter Hohmann Observatory, Essen, Germany, helena_relke@yahoo.com
}

ABSTRACT. We have initiated the search of asteroids and comets on the basis of the processing digital images of plates obtained in the framework of FON project (the photographic survey of the northern hemisphere), Dushanbe section of the observational program. The result is the catalog of positions of the Solar System minor bodies. Observations were obtained in 1985-1992 at the Hissar Astronomical observatory of TajikINASTR (Institute of Astrophysics of the Academy of Sciences of Republic of Tajikistan) on the Zeiss-400 astrograph (Marsden's code $190, \mathrm{D} / \mathrm{F}=400 / 2000 \mathrm{~mm})$. The plate collection includes around 1570 negatives covered the northern hemisphere from $-8^{\circ}$ to $+90^{\circ}$. The plate digitization has started in 2017 after the commercial scanner Microtek ScanMaker 1000XL Plus was provided. The scanner was previously tested for systematic errors and proved for suitability for digitizing photographic plates. The joint research of MAO NAS of Ukraine and Hissar observatory on Dushanbe glass collection reduction has started in 2017. The astrometric reduction of digitized plates is conducted using the software developed in MAO NAS of Ukraine running in the LINUX/MIDAS/ROMAPHOT complex. To the current moment, $10 \%$ of the collection (171 plates) has been processed. For each fixed object we obtain positions in the TYCHO2 reference system. For stars in the magnitude range $5^{\mathrm{m}}-17^{\mathrm{m}}$ positional errors were estimated as \pm 0.36 arcsec, and B-magnitudes' errors were found $\pm 0.12^{\mathrm{m}}$. Stars and galaxies are not the only objects registered on the plates. During the observations, such objects as comets and asteroid could occasionally get on the picture. Here, we present the first results of the search for such objects on the FON photographic plates. The search and the evaluation of the convergence of minor bodies' observed positions with the theoretic predictions are carried out online by jpl ephemerid service (https://ssd.jpl.nasa.gov/sbfind).

Keywords: FON project, digital plate processing, astrometry of asteroids and comets.
АБСТРАКТ. Робота присвячена пошуку та визначенню положень малих тіл Сонячної системи на базі спостережного матеріалу програми ФОН-Душанбе. У 1985-1992 роках Гіссарська Астрономічна обсерваторія Інституту астрофізики Академії наук Республіки Таджикістан приймала участь у проекті ФОН. За допомогою астрографа Ц-400 (Marsden's code $190, \mathrm{D} / \mathrm{F}=400 / 2000 \mathrm{~mm})$ будо отримано майже 1570 фотографічних платівок зоряного неба в межах від $-8^{\circ}$ до $+90^{\circ}$ град. До опрацювання цих платівок впритул підійшли тільки у 2017 році, коли було придбано професійний сканер Microtek ScanMaker 1000XL Plus та виконано його дослідження. $\mathrm{y}$ цьому ж році започатковано спільну з ГАО НАН України роботу 3 подальшої редукції цих спостережень за допомогою комплексу програм в операційному середовищі LINUX/MIDAS/ROMAPHOT. Ці програми були спеціально розроблені та запроваджені для здійснення усього проекту ФОН. На даний момент опрацьовано близько $10 \%$ фотографічних спостережень, що були отримані у Гіссарській Астрономічній обсерваторії. Визначено екваторіальні координати всіх об'єктів на кожній з 171 пластинки по відношенню до опорної системи каталогу ТYCHO2. Похибки екваторіальних координат $\sigma_{\alpha \delta}$ становлять $\pm 0.36 \mathrm{arcsec}$, а похибки Bвеличин $\sigma_{\mathrm{B}}$ дорівнюють $\pm 0,12 \mathrm{mg}$ в межах діапазону зоряних величин від от $5 \mathrm{mg}$ до $17 \mathrm{mg}$. Астронегативи фотопластинок, отримані за програмою ФОН, зберігають в собі неоціненну інформацію про динамічний стан Космосу у певний момент часу. У роботі досліджуються результати позапланових спостережень малих планет Сонячної системи (МП). Після обробки фотографічних пластинок за програмою ФОН-Душанбе розпочато роботу 3 ототожнення зображень астероїдів і комет (МП) на цих астронегативах. Пошук МП та оцінка узгодженості між спостережними та їх теоретичними положеннями здійснюється у режимі online за допомогою jpl-ефемерид інтернет-сервісу (https://ssd.jpl.nasa.gov/sbfind).

Ключові слова: проект ФОН, опрацювання оцифрованих пластинок, астрометрія астероїдів та комет. 


\section{Introduction}

The plan of the four-fold covering of the northern sky with the photographic plates of the set of the same wideangle astrographs was developed and firstly presented in $70^{\text {th }}$ of last century by scientists of MAO NAS of Ukraine I.G. Kolchinsky and A.B. Onegina. (Kolchinsky, 1977; Pakuliak, 2016). 6 observatories of the former USSR equipped with the same Carl Zeiss Jena astrographs (apertures $400 \mathrm{~mm}$ and phocal lengths 2000 or $3000 \mathrm{~mm}$ ) were involved in the realization of this project. Observational periods and periods of plate processing for each observatory were different. Thus, in the framework of UkrVO project (Vavilova, 2012a; Vavilova, 2012b; Vavilova, 2014; Vavilova, 2016; Vavilova, 2017) the Golosiiv part of the FON program was completed (Andruk, 2015; Andruk, 2016a; Andruk, 2016b; Andruk, 2017a), in 2017 г. the Kitab part of the FON program was presented (Yuldoshev, 2016; Andruk, 2017b; Yuldoshev, 2017a; Yuldoshev, 2017b). At the Hissar Astronomical observatory of TajAPHI (Institute of Astrophysics of the Academy of Sciences of Tajikistan), the efforts on the FON-Dushanbe photographic collection processing have been undertaken in 2017 (Mullo-Abdolov, 2017; MulloAbdolov, 2018; Rahimi, 2018). The total number of plates is around 1570. Years of observation cover 1985-1992. Plates were obtained on the Carl Zeiss Jena astrograph (Marsden's code 190, D/F=400/2000 mm). Each plate was shot with two exposures of different duration with the shift between expositions by certain distance on both coordinates (Andruk, 2012). The short exposition was 40-60 sec, the second, the main, lasting 18-27 min. Linear dimensions of plates are $30 \times 30 \mathrm{~cm}(13000 \times 13000$ pixels $)$ covering the star field $8^{\circ} \times 8^{\circ}$. Full descriptions of observational conditions for each plate from the original observational logs were compiled into digital logbook file. The processing of the observational material started after the commercial flat-bed scanner Microtek ScanMaker 1000XL Plus was provided in the TajAPHI. The tests of the scanner, performed on the test plates with the Pleiades cluster, showed that the scanner could provide the astrometric precision of $\sigma_{\alpha \delta}=0.13 "$. The astrometric reduction of digital images was carried out using the software proposed and developed in MAO NAS of Ukraine. The whole process runs in LINUX/MIDAS/ROMAPHOT with TYCHO2 as reference [Andruk, 2015]. The result of proceeding of a small part of FON glass collection (10\%) has shown that stars in the range of magnitudes $5^{\mathrm{m}} \ldots 17^{\mathrm{m}}$ have positional errors $\sigma_{\alpha \delta}=0.36$ arcsec, errors of Bmagnitudes are $\sigma_{\mathrm{B}}=0,12^{\mathrm{m}}$. B-magnitudes were obtained in the reference system of photoelectric $B_{\mathrm{pe}}$ standards used for the restoration of characteristic curves of separate negatives. Reference stars with photoelectric magnitudes were taken from the catalog by [Relke, 2015]. The final aim of the whole collection treatment is the catalog of positions and magnitudes of all objects down to $17^{\mathrm{m}}$ registered on the plates. Occasionally, during the observations, some asteroids and comets passing by the observed area at the moment of the shooting were registered on the photographic plates. The identification of asteroids can be performed using internet-service (https://ssd.jpl.nasa.gov). From the service, we obtained the list of ephemeris positions of minor planets in observed sky area at the moment of observations $\mathrm{UT} \pm 1 \mathrm{~min}$.

\section{The scheme of minor planet identification}

So, for the moment of observation, there are two files for each plate. One of them contains the results of digitized plate reduction. The next one includes ephemeris positions of asteroids and comets in the area of the processed plate. The comparison of data in two files gives the catalog of topocentric positions of all minor planets, got onto the photographic plate. The step-by-step process of the determination of astrometric positions of minor planets from the plates of FON-Dushanbe is as follows:

1. On the first step, for the plate of interest we select the information of observational conditions from the digital log file, namely the moment of its exposure in the units of sidereal time "Mean Sidereal Time in the middle of a long exposure". Then, the sidereal moment is transformed into the universal time scale UT.

2. On the web-page "Solar System Dynamics on-line Tools" of the service https://ssd.jpl.nasa.gov in the section "The small-body identification" we insert the main search parameters for minor planets: date/moment (UT $\pm 1 \mathrm{~min}$ ) of observation, location of the observer, coordinates of the plate center, and borders of the sky area covered with the plate taking into account the plate corners declinations.

The output contains the nominal list of ephemeris positions of all minor planets got into the outlined area.

3. On the next step, the search script of the software compares data of two files in order to detect the intended asteroids and comets among the objects registered on the plate. The output file contains the comparison results of observed and theoretical values: $(\mathrm{O}-\mathrm{C}) \alpha,(\mathrm{O}-\mathrm{C}) \delta$, (B-V)mg.

4. The link "Web-Interface" in the "JPL's HORIZONS System" allows deriving the improved ephemeris data for the moment of observation (UT $\pm 1 \mathrm{sec}$ ).

\section{Discussion of the search results}

To the moment, 71 plates of the zero zone $\left(\alpha=0^{\mathrm{h}} \ldots\right.$ $\left.24^{\mathrm{h}}, \delta=0^{\circ} \pm 4^{\circ}\right)$ and 100 plates of the circumpolar zone $(\delta=$ $64^{\circ} \ldots 84^{\circ}$ ) have been processed. With the help of the jplephemeris (https://www.jpl.nasa.gov), 104 asteroids were identified on 42 plates, and the list of 117 their topocentric positions was obtained. The comparison of these positions with the ephemeris data has shown that the essential part of minor planets' observations in the Hissar observatory has the significant discrepancies with the theory. Yet, the results of observations of the same objects at MAO NAS of Ukraine show the good agreement when comparing to the ephemerid (Shatokhina, 2017; Shatokhina, 2018a). The above-said technique is now applied for completion of the search of asteroids and comets in the photographic collection of FON-Kitab part of the project (Shatokhina, 2018b). Earlier, this technique was tested for the search of satellites of major planets of the Solar System (Yizhakevych, 2014; Yizhakevych, 2015; Yizhakevych, 2016; Yizhakevych, 2017a; Yizhakevych, 2017b). 
Table 1. Comparison of asteroid search results on the plates in the declination zone 00 obtained in Gissar observatory (190) and MAO NAS of Ukraine (083)

\begin{tabular}{|c|c|c|c|c|c|c|c|c|c|c|}
\hline Name & code & Npl. & \multicolumn{2}{|c|}{ Date, UT } & OCal" & OCdl” & Bph & Vmg & B-V \\
\hline 1 & 2 & 3 & 4 & 5 & 6 & 7 & 8 & 9 & 10 & 11 \\
\hline 24 & 190 & 1058 & 1989 & 09 & 1.885364 & -2.25 & -0.04 & 12.60 & 12.36 & 0.24 \\
\hline 24 & 190 & 1196 & 1992 & 04 & 7.797387 & -0.60 & 0.56 & 11.17 & 10.96 & 0.21 \\
\hline 24 & 083 & 1504 & 1989 & 09 & 21.930227 & -0.20 & -0.27 & 12.54 & 11.95 & 0.59 \\
\hline 24 & 083 & 1515 & 1989 & 10 & 25.800329 & -0.04 & 0.02 & 13.29 & 12.31 & -0.98 \\
\hline & & & & & & & & & & \\
\hline 47 & 190 & 1058 & 1989 & 09 & 01.885364 & 2.25 & -0.53 & 12.25 & 11.59 & 0.66 \\
\hline 47 & 083 & 821 & 1986 & 02 & 26.700712 & 0.66 & -0.26 & 14.96 & 13.48 & 1.48 \\
\hline 47 & 083 & 822 & 1986 & 02 & 26.718141 & 0.28 & -0.39 & 13.62 & 13.48 & 0.14 \\
\hline 47 & 083 & 1504 & 1989 & 09 & 21.930227 & 0.07 & -0.06 & 11.26 & 11.08 & 0.18 \\
\hline 47 & 083 & 1510 & 1989 & 10 & 19.817000 & -0.23 & 0.16 & 12.69 & 11.45 & 1.24 \\
\hline 47 & 083 & 1957 & 1992 & 02 & 26.951613 & -0.50 & -0.02 & 13.08 & 12.39 & 0.69 \\
\hline & & & & & & & & & & \\
\hline 1142 & 190 & 1058 & 1989 & 09 & 1.885364 & -1.65 & -0.70 & 15.91 & 15.23 & 0.68 \\
\hline 1142 & 083 & 1964 & 1992 & 02 & 28.845964 & -0.12 & 0.76 & 16.19 & 15.21 & 0.98 \\
\hline & & & & & & & & & & \\
\hline 1381 & 190 & 1058 & 1989 & 09 & 01.885364 & -3.15 & -0.98 & 14.95 & 14.90 & 0.05 \\
\hline 1381 & 083 & 1510 & 1989 & 10 & 19.817000 & -0.27 & 0.42 & 15.41 & 14.87 & 0.54 \\
\hline & & & & & & & & & & \\
\hline 1408 & 190 & 1281 & 1990 & 10 & 14.731300 & -1.50 & -0.64 & 15.73 & 15.49 & 0.24 \\
\hline 1408 & 083 & 1718 & 1990 & 10 & 11.842910 & -0.03 & -0.34 & 16.10 & 15.42 & 0.68 \\
\hline & & & & & & & & & & \\
\hline 1425 & 190 & 1423 & 1992 & 05 & 04.771185 & -0.60 & 0.01 & 14.86 & 14.58 & 0.28 \\
\hline 1425 & 083 & 1735 & 1990 & 10 & 14.086536 & -0.74 & -1.20 & 17.00 & 15.94 & 1.06 \\
\hline 1425 & 083 & 1978 & 1992 & 04 & 23.920175 & 0.34 & 0.12 & 14.70 & 14.37 & 0.33 \\
\hline & & & & & & & & & & \\
\hline 1691 & 190 & 1281 & 1990 & 10 & 14.731300 & -2.55 & -0.80 & 15.48 & 15.06 & 0.42 \\
\hline 1691 & 083 & 1920 & 1992 & 01 & 08.929235 & -0.60 & 0.15 & 15.24 & 14.84 & 0.40 \\
\hline
\end{tabular}

Below Table 1 shows results of comparing the observations of seven asteroids obtained at two observatories, Hissar observatory and MAO NAS of Ukraine. Columns in Table 1 contain the following data: 1 - asteroid number, 2 - Marsden's code, 3 - plate number, 4-5-6 - year, month, day + UT in fractions of day, $7-(\mathrm{O}-$ C)" R.A., 8 - (O-C)" Dec., 9 - photometric value Bph, 10 visual magnitude $\mathrm{Vmg}, 11-(\mathrm{Bph}-\mathrm{V})$. The possible reason for discrepancies in observed and theoretical positions of minor planets could be the errors of moments' registration in Hissar observatory, namely the underestimation of chronometer corrections. This is primarily evidenced by discrepancies in (O-C) on right ascension. For example, by the previous estimations, the error in the moment registration for the plate number 1058 containing the images of 5 minor planets could reach $4.5 \mathrm{~min}$.

\section{Some conclusions}

Using the JPL-ephemerids and the search program of MAO NAS of Ukraine software for digital plate processing the identification of minor bodies was made for 171 plates of FON-Dushanbe plate collection. The research on asteroids and comets identification follows the original FON-Dushanbe project astrometric treatment of observations. The most effective is the zero declination zone where 117 topocentric positions for 104 asteroids were derived by the processing of 42 plates. For the determination of dynamic characteristics of minor planets besides positions, it is necessary to have the precise data of registration moment. In our case, additional efforts are required to resolve the problem with determining the exact moments of observations. 
After completion of processing all the plates for the FON project, the number of plates with images of minor planets obtained during the same night may increase. Perhaps this will allow, if not to determine the time of exposure of the plate, then at least to estimate the magnitude of its error, which is important in the study of the dynamic processes in the Universe.

Acknowledgements. The authors are thankful to academician Farhod Rahimi, the President of Academy of Sciences of the Republic of Tajikistan, for the supporting of the project "FON-Dushanbe catalogue".

\section{Reference}

Andruk V.M., Ivanov G.A., Yatsenko A.I. et al.: 2012, BTSNU, 48, 11.

Andruk V.M., Pakuliak L.K., Golovnia V.V. et al.: 2015, Odessa Astron. Publ., 28, 192.

Andruk V.M., Golovnia V.V., Ivanov G.A. et al.: 2016, Kinem. Phys. Cel. Bodies, 32, N1, 38.

Andruk V.M., Pakuliak L.K., Golovnia V.V. et al.: 2016, Kinem. Phys. Cel. Bodies, 32, N5, 260.

Andruk V.M., Pakuliak L.K., Golovnia V.V. et al.: 2017 , Scince and Innovation, 13a, 17.

Andruk V., Yuldoshev Q., Eglitis I. et al.: 2017, Odessa Astron. Publ., 30, 159.

Eglitis I., Eglite M., Shatokhina S.V. et al.: 2016, Odessa Astron. Publ., 29, 123.

Kolchinsky I.G., Onegina A.B.: 1977, Astrometry and Astrophysics, 33, 11.

Mullo-Abdolov A., Kokhirova A., Relke H. et al.: 2017, Odessa Astron Publ., 30, 186.

Mullo-Abdolov A., Relke H., Kokhirova A. et al.: 2018, Odessa Astron Publ., 31, .

Pakuliak L.K., Andruk V.M., Golovnia V.V. et al.: 2016, Odessa Astron. Publ., 29, 132.
Rahimi F., Mullo-Abdolov A.Sh., Kokhirova G.I. et al.: RpAST, 2018, 61, N2, 144.

Relke E., Protsyuk Yu.I., Andruk V.M.: 2015, Odessa Astron. Publ., 28, 211.

Shatokhina S.V., Kazantseva L.V., Yizhakevych O.M. et al.: 2017, Odessa Astron. Publ., 30,198.

Shatokhina S.V., Kazantseva L.V., Yizhakevych O.M. et al.: 2018, Kinem. Phys. Cel. Bodies, 34, N5, 70.

Shatokhina S.V., Relke H., Yuldoshev Q. et al.: 2018, Odessa Astron. Publ., 31, .

Vavilova I.B., Pakulyak L.K., Shlyapnikov A.A. et al.:2012, Kinem. Phys. Cel. Bodies, 28, N2, 85.

Vavilova I.B., Pakuliak L.K., Protsyuk Yu.I. et al.:2012, Baltic Ast., 21, N3, 356.

Vavilova, I.B., Golovnya, V.V., Andruk, V.M. et al.: 2014., Odessa Astron. Publ., 27, 132.

Vavilova I.B.: 2016, Odessa Astron. Publ., 29, 109.

Vavilova I.B., Yatskiv Ya.S., Pakuliak L.K. et al.: 2017, IAUS, 325, 361.

Yizhakevych O.M., Andruk V.M., Pakuliak L.K. et al.: 2014, Odessa Astron Publ., 27, 67.

Yizhakevych O.M., Andruk V.M., Pakuliak L.K. 2015, Odessa Astron Publ., 28, 213.

Yizhakevych O.M., Andruk V.M., Pakuliak L.K. 2016, Odessa Astron Publ., 29, 155.

Yizhakevych O.M., Andruk V.M., Pakuliak L.K. 2017, Odessa Astron Publ., 30, 201.

Yizhakevych O.M., Andruk V.M., Pakuliak L.K. 2017, Kinem. Phys. Cel. Bodies, 33, N3, 142.

Yuldoshev Q.X., Muminov M.M., Ehgamberdiev Sh.A. et. al.: 2016, Odessa Astron Publ., 29, 160.

Yuldoshev Q.X., Muminov M.M., Ehgamberdiev Sh.A. et. al.: 2017, Odessa Astron Publ., 30, 205.

Yuldoshev Q.X., Ehgamberdiev Sh.A., Muminov M.M. et al.: 2017, Kinem. Phys. Cel. Bodies, 33, N5, 250. 